\title{
MIL/Aptamer as a Nanosensor Capable of Resisting Nonspecific Displacement for ATP Imaging in Living Cells
}

Jun Li,,$^{\dagger}$ Yuedong Zhang, ${ }^{\dagger}$ Zhen Zou, ${ }^{\dagger}$ Zhihe Qing, ${ }^{\dagger}$ Sheng Yang, ${ }^{\dagger}$ Jianxiao Yang,, Lihua Zhang ${ }^{\S}$, Feng Feng, ${ }^{\S}$ and Ronghua Yang ${ }^{\dagger, \S, *}$

†School of Chemistry and Food Engineering, Changsha University of Science and Technology, Changsha, 410114, P. R. China;

$\$$ College of Materials Science and Engineering, Hunan University, Changsha, 410082, P. R. China;

${ }^{\S}$ College of Chemistry and Environmental Engineering, Shanxi Datong University, Datong, Shanxi, 037009, P. R. China.

*To whom correspondence should be addressed:

E-mail: yangrh@pku.edu.cn, Fax: +86-731-8882 2523 


\section{Contents}

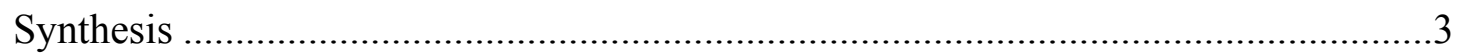

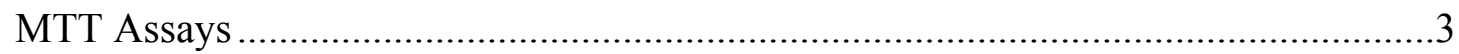

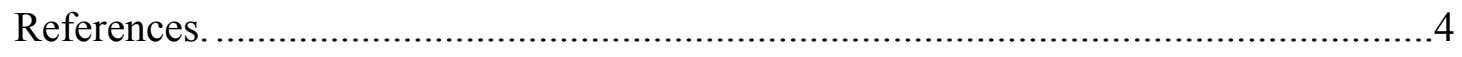

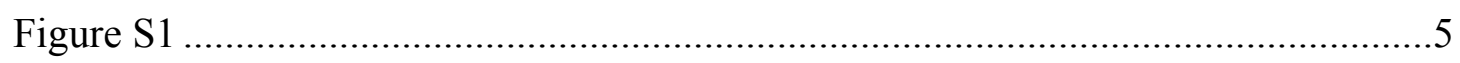

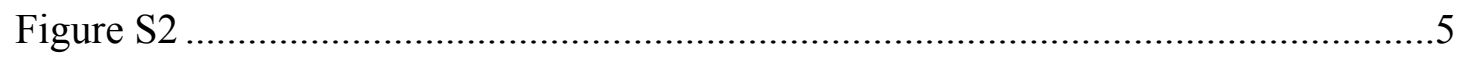

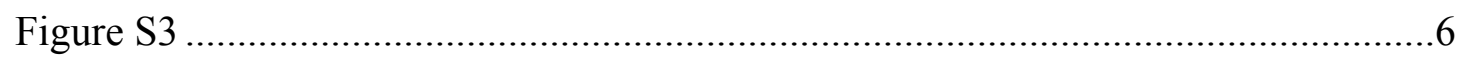

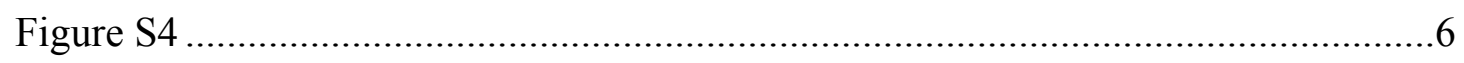

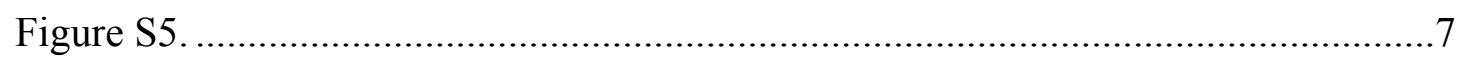

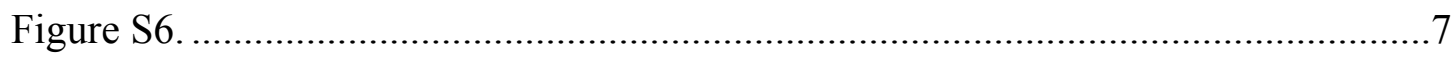

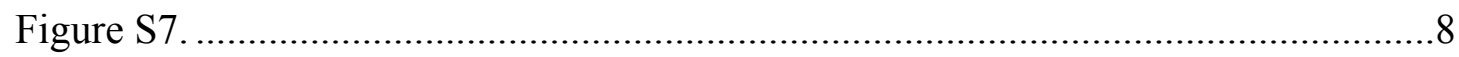

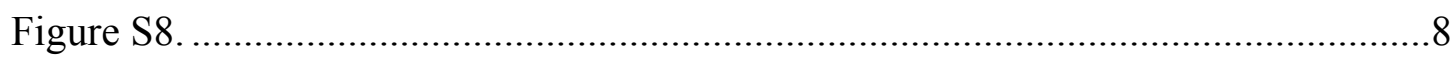

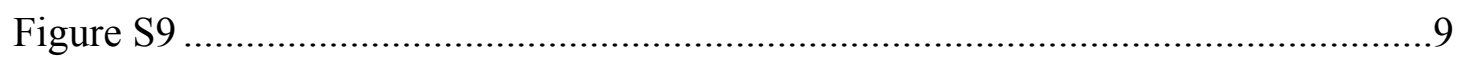

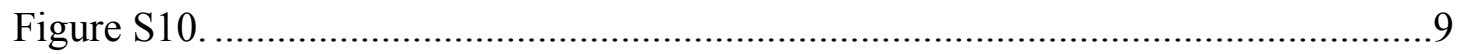

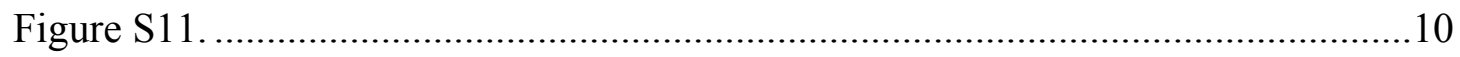

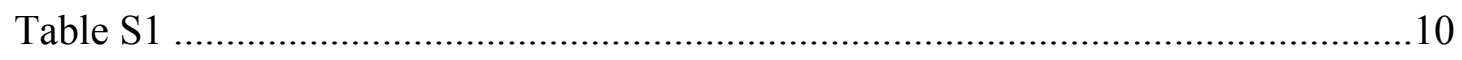




\section{Synthesis}

Synthesis of MIL-100. MIL-100 was synthesized following the reported procedure. ${ }^{1}$ Reduced iron powder (1.0 mmol, $56 \mathrm{mg})$, benzene-1,3,5-tricarboxylic acid (BTC, 0.66 mmol, $139 \mathrm{mg}), \mathrm{HF}$ aqueous solution $(47 \%, 1.04 \mathrm{mmol}, 40 \mathrm{mg}), \mathrm{HNO}_{3}(1.2 \mathrm{mmol}, 83 \mu \mathrm{L})$ and $\mathrm{H}_{2} \mathrm{O}(280 \mathrm{mmol}, 5 \mathrm{~mL})$ were placed in a $20 \mathrm{~mL}$ Teflon-liner autoclave and heated at $150{ }^{\circ} \mathrm{C}$ for $144 \mathrm{~h}$, then cooled down to room temperature for $24 \mathrm{~h}$. The resulting solid was centrifuged and washed with $\mathrm{H}_{2} \mathrm{O}$ for three times, and finally dried overnight at $150{ }^{\circ} \mathrm{C}$ under vacuum for further use.

Synthesis of $\mathbf{C u}\left(\mathrm{H}_{2}\right.$ dtoa). $\mathrm{Cu}\left(\mathrm{H}_{2}\right.$ dtoa $)$ was synthesized using the literature methods. ${ }^{2,3}$ $10 \mathrm{~mL} \mathrm{5 \%} \mathrm{H}_{2} \mathrm{dtoaH}_{2}$ ethanol solution was added to $20 \mathrm{~mL}$ lukewarm $\mathrm{CuSO}_{4}$ aqueous solution with continuous stirring. The black precipitate was centrifuged and washed with $\mathrm{H}_{2} \mathrm{O}$ and ethanol several times, and then dried in an evacuated desiccator for the following experiment.

\section{MTT Assays}

HeLa cells were seeded into a 96-well plate at a concentration of $5 \times 10^{3}$ cells well ${ }^{-1}$ and maintained at $37{ }^{\circ} \mathrm{C}$ in $5 \% \mathrm{CO}_{2}$ for $48 \mathrm{~h}$. Next, the cells were incubated with different concentrations of MIL/Apt-F $(0-300 \mu \mathrm{g} / \mathrm{mL})$ for $24 \mathrm{~h}$, and then they were washed with PBS for three times, followed by adding $100 \mu \mathrm{L}$ MTT solution $(0.5$ $\mathrm{mg} / \mathrm{mL}$ in PBS) to each well. After addition of DMSO $(150 \mu \mathrm{L} /$ well $)$, the assay plate was allowed to shake at room temperature for $10 \mathrm{~min}$. Absorbance was measured at $570 \mathrm{~nm}$ by using a microplate reader. 


\section{References}

(1) Zhang, J. W.; Zhang, H. T.; Du, Z. Y.; Wang, X. Q.; Yu, S. H.; Jiang, H. L. Water-Stable Metal-Organic Frameworks with Intrinsic Peroxidase-Like Catalytic Activity as a Colorimetric Biosensing Platform. Chem. Commun. 2014, 50, 1092-1094.

(2) Zhu, X.; Zheng, H. Y.; Wei, X. F.; Lin, Z. Y.; Guo, L. H.; Qiu, B.; Chen, G. N. Metal-Organic Framework (MOF): A Novel Sensing Platform for Biomolecules. Chem. Commun. 2013, 49, 1276-1278.

(3) Hai, X. M.; Li, N.; Wang, K.; Zhang, Z. Q.; Zhang, J.; Dang, F. Q. A Fluorescence Aptasensor Based on Two-Dimensional Sheet Metal-Organic Frameworks for Monitoring Adenosine Triphosphate. Analytica Chimica Acta. 2018, 998, 60-66.

(4) Liu, Z. B.; Chen, S. S.; Liu, B. W.; Wu, J. P.; Zhou, Y. B.; He, L. Y.; Ding, J. S.; Liu, J. W. Intracellular Detection of ATP Using an Aptamer Beacon Covalently Linked to Graphene Oxide Resisting Nonspecific Probe Displacement. Anal. Chem. 2014, $86,12229-12235$.

(5) Tan, X. H.; Chen, T.; Xiong, X. L.; Mao, Y.; Zhu, G. Z.; Yasun, E.; Li, C.; Zhu, Z.; Tan, W. H. Semiquantification of ATP in Live Cells Using Nonspecific Desorption of DNA from Graphene Oxide as the Internal Reference. Anal. Chem. 2012, 84, $8622-8627$. 

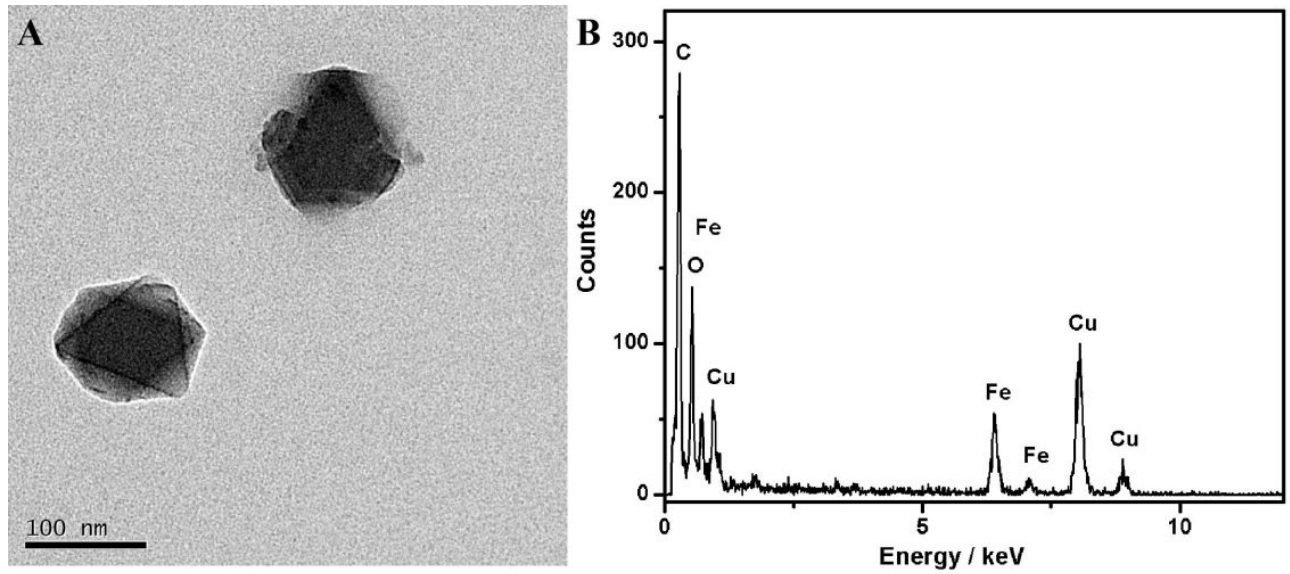

Figure S1. Representative (A) TEM image and (B) EDX spectrum of the as-synthesized MIL-100. The signals of $\mathrm{Cu}$ in (B) were from the TEM grid.

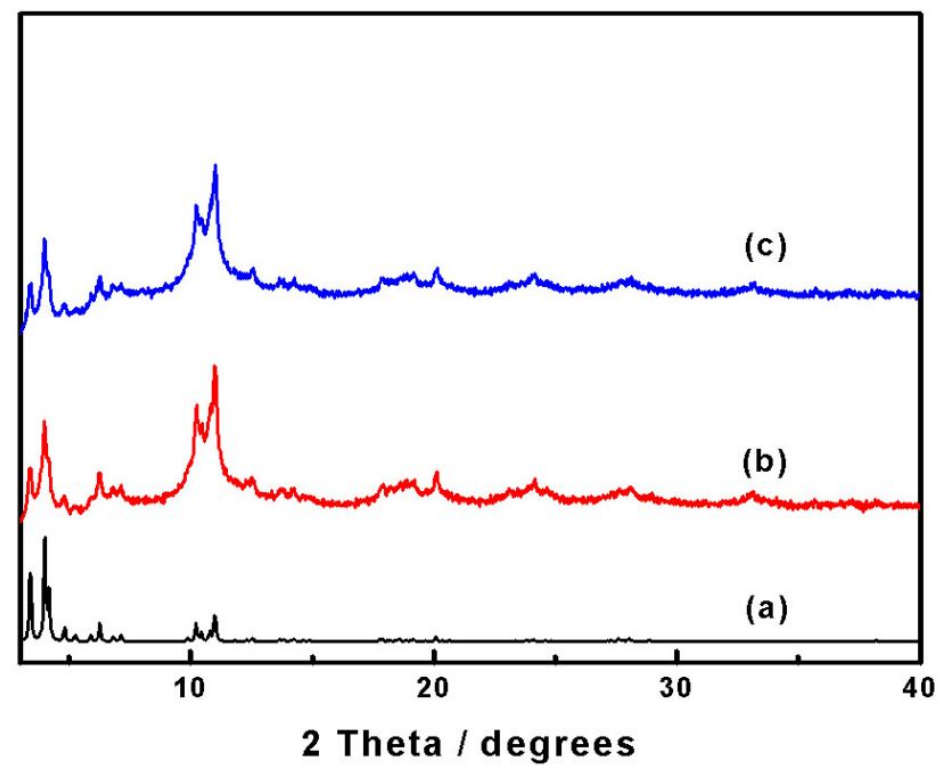

Figure S2. Powder X-ray diffraction (XRD) profiles of (a) simulated MIL-100, (b) as-synthesized MIL-100 and (c) MIL-100 immersed in the Tris-HCl buffer solution (20 mM, pH 7.2) for $24 \mathrm{~h}$. 


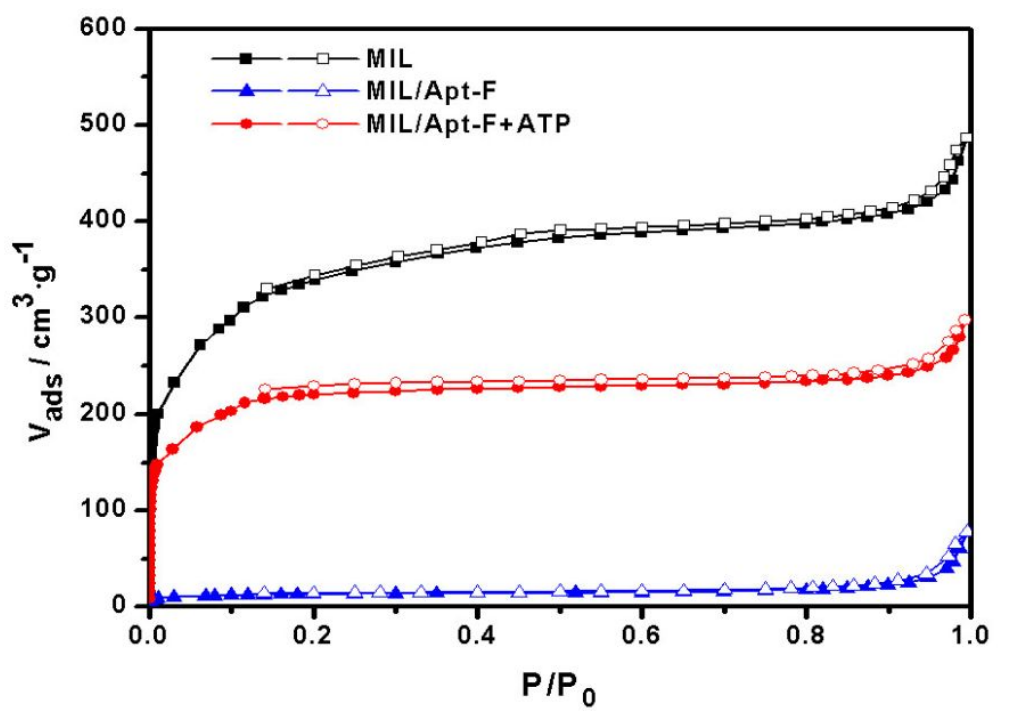

Figure S3. $\mathrm{N}_{2}$ sorption isotherms of MIL-100, and MIL/Apt-F nanosensor before and after reaction of ATP. The BET surface areas of the three samples are 820, 49 and 805 $\mathrm{m}^{2} / \mathrm{g}$, respectively. (Filled and open symbols represent adsorption and desorption branches, respectively.)

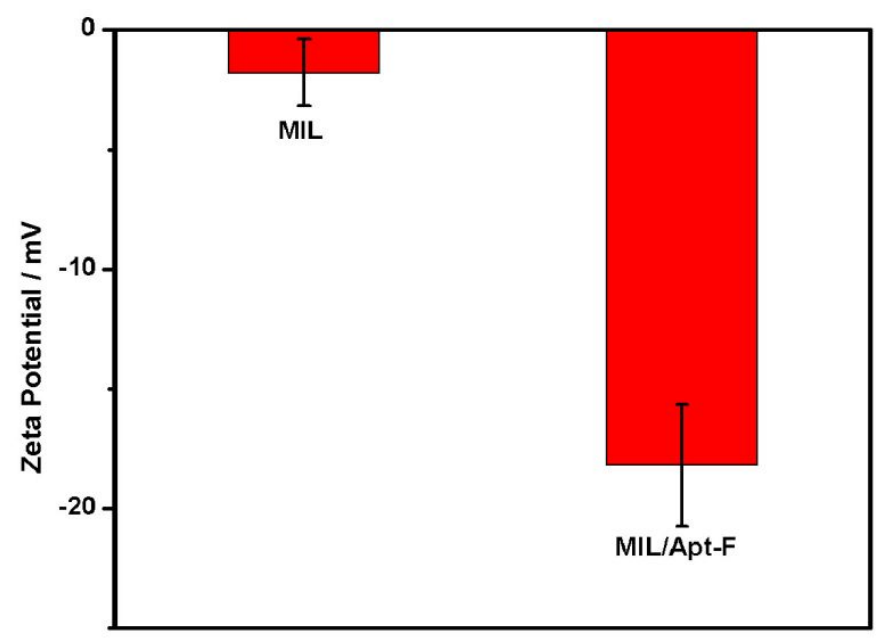

Figure S4. Zeta potentials of MIL-100 and MIL/Apt-F nanosensor. Error bars indicate s.d. $(n=3)$. 

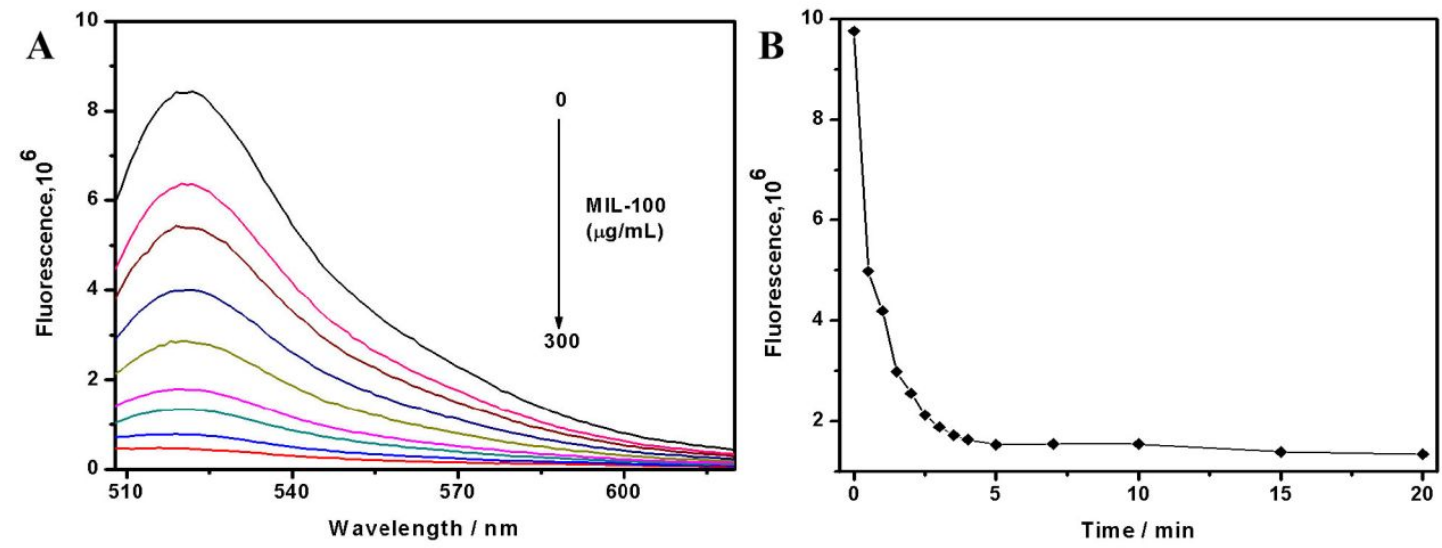

Figure S5. (A) Fluorescence intensity of Apt-F $\left(10 \mathrm{nM}, \lambda_{\mathrm{ex}}=485 \mathrm{~nm}\right)$ upon introduction of different concentrations of MIL-100 (0, 40, 80, 120, 160, 200, 240, $280,300 \mu \mathrm{g} / \mathrm{mL}$ ); (B) the influence of the incubation time on the fluorescence intensity at $520 \mathrm{~nm}$ of $10 \mathrm{nM}$ Apt-F in the presence of $300 \mu \mathrm{g} / \mathrm{mL}$ MIL-100.
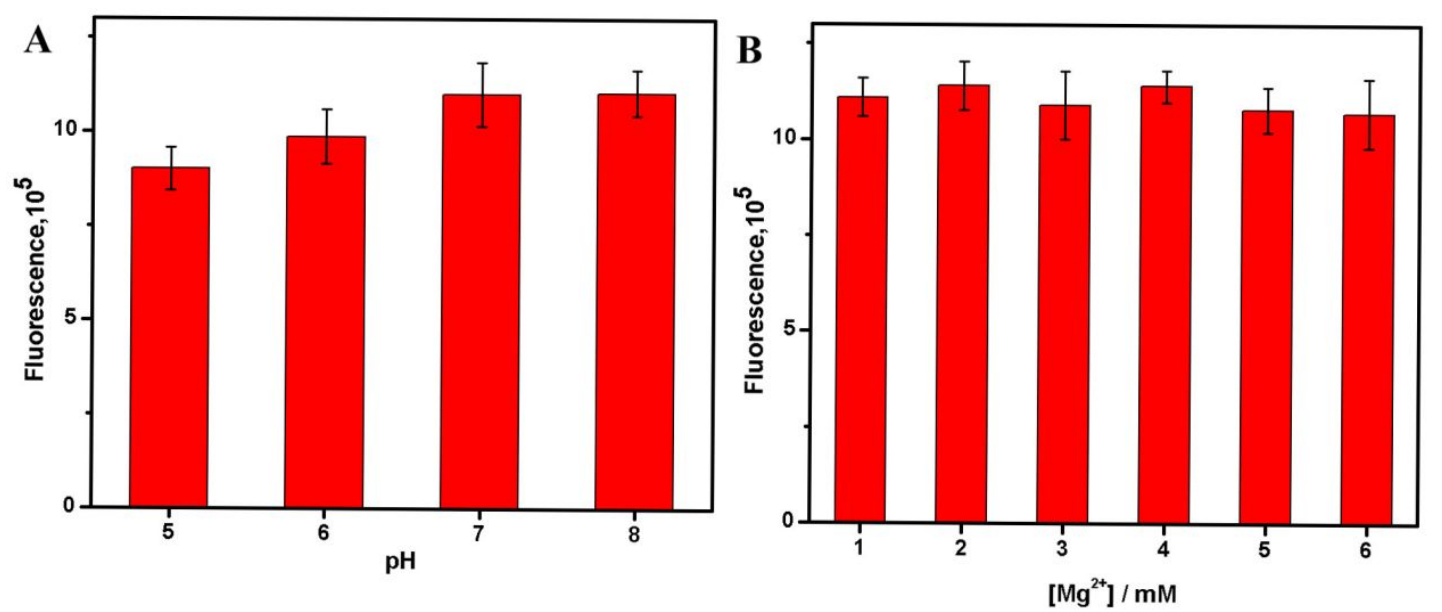

Figure S6. The stability of the MIL/Apt-F nanosensor. Fluorescence intensity of the nanosensor $(0.3 \mathrm{mg} / \mathrm{mL})$ at biological $\mathrm{pH}$ range $(\mathrm{A})$ and various $\mathrm{Mg}^{2+}$ ionic concentrations $(5,10,20,40,70,100 \mathrm{mM})(B)$. Error bars indicate s.d. $(\mathrm{n}=3)$. 


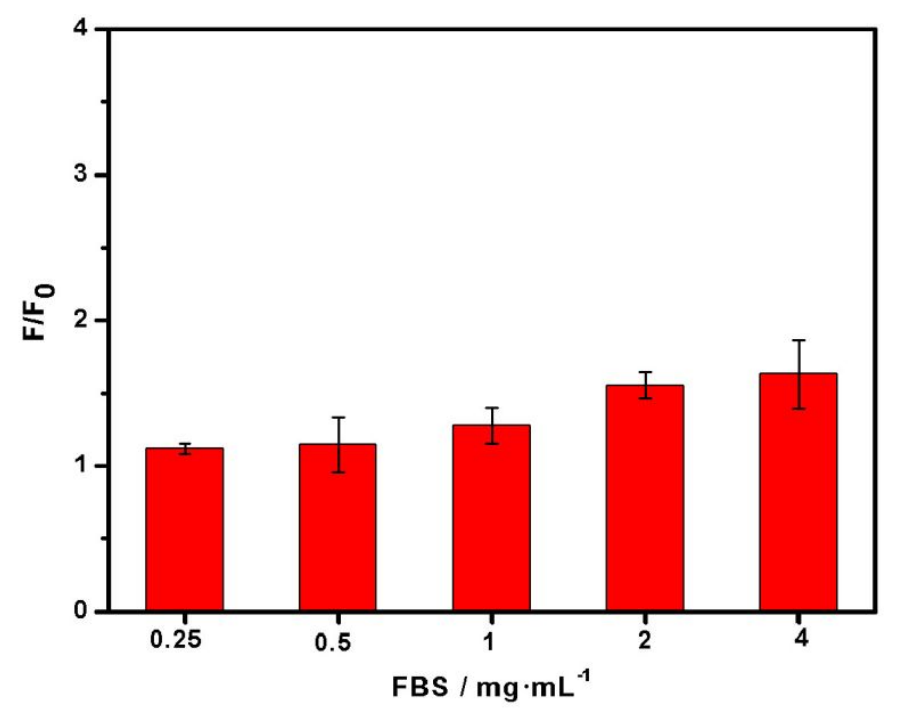

Figure S7. The MIL/Apt-F nanosensor responses to various concentrations of fetal bovine serum (FBS). Error bars indicate s.d. $(\mathrm{n}=3)$.

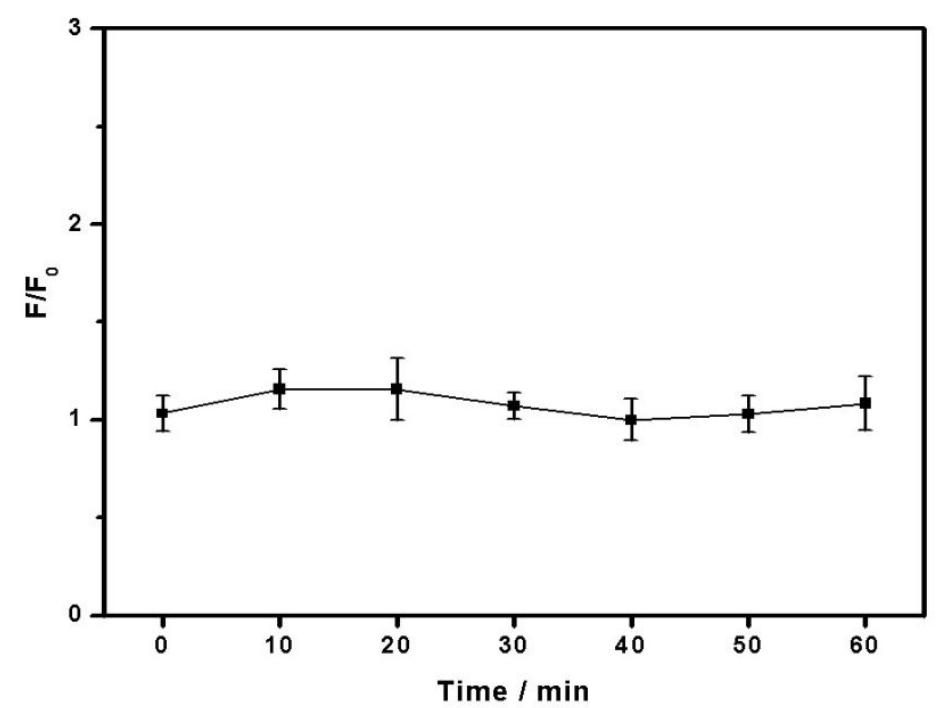

Figure S8. The protective effect of MIL/Apt-F nansosensor on DNA against nuclease-mediated degradation. Fluorescence emission spectra $\left(\lambda_{\mathrm{ex}}=485 \mathrm{~nm}, \lambda_{\mathrm{em}}=520\right.$ $\mathrm{nm})$ of MIL/Apt-F upon incubation with $3 \mathrm{U} / \mathrm{mL}$ DNase I in Tris-HCl $(20 \mathrm{mM}$, pH 7.2) for different time at $37^{\circ} \mathrm{C} . F_{0}$ is the fluorescence intensity at the start of the degradation reaction, and $F$ is that at the corresponding time point. 


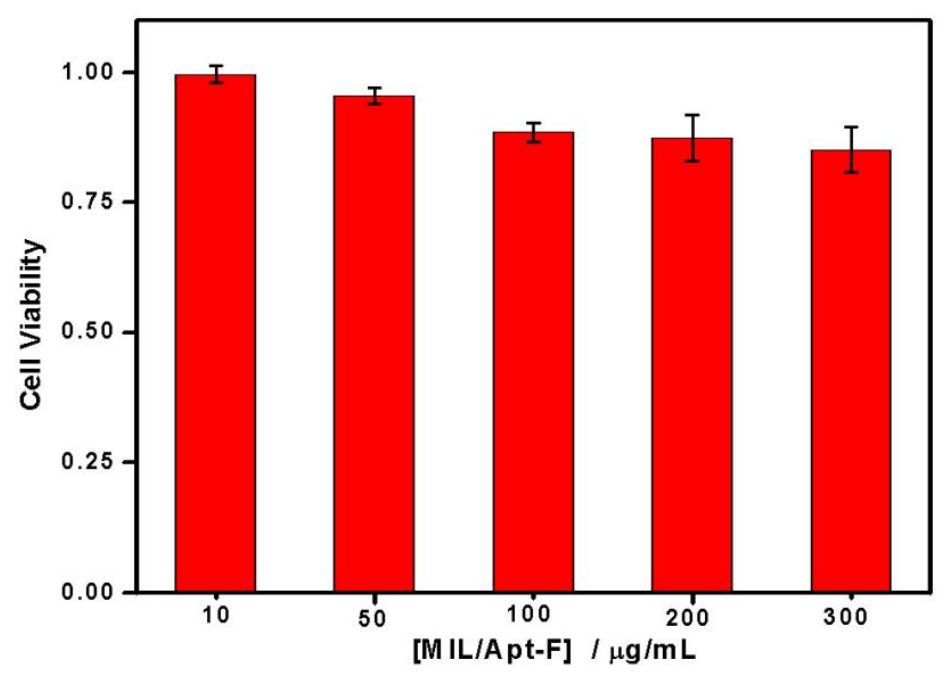

Figure S9. Cell viability of HeLa cells treated with different concentrations of the MIL/Apt-F nanosensor for 24 h. Error bars indicate s.d. $(n=3)$.

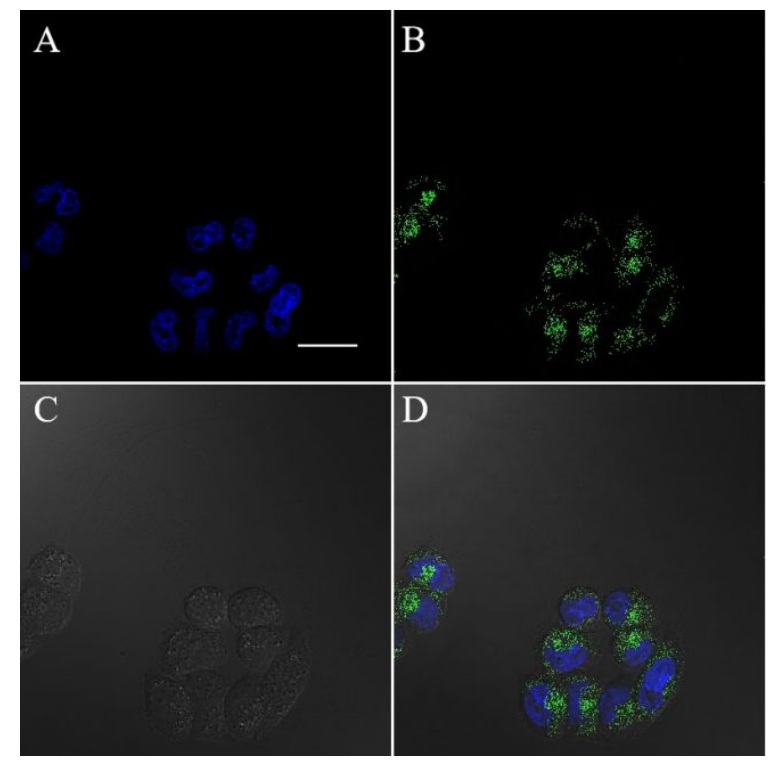

Figure S10. CLSM images of HeLa cells after incubation with MIL/Apt-F nanosensor $(0.3 \mathrm{mg} / \mathrm{mL})$ for $8 \mathrm{~h}$. (A) The nuclei of cells being dyed in blue by Hoechst 33342; (B) FAM image; (C) Bright-field image of HeLa cells; (D) Overlay of (A-C). Scale bar: $20 \mu \mathrm{m}$. 


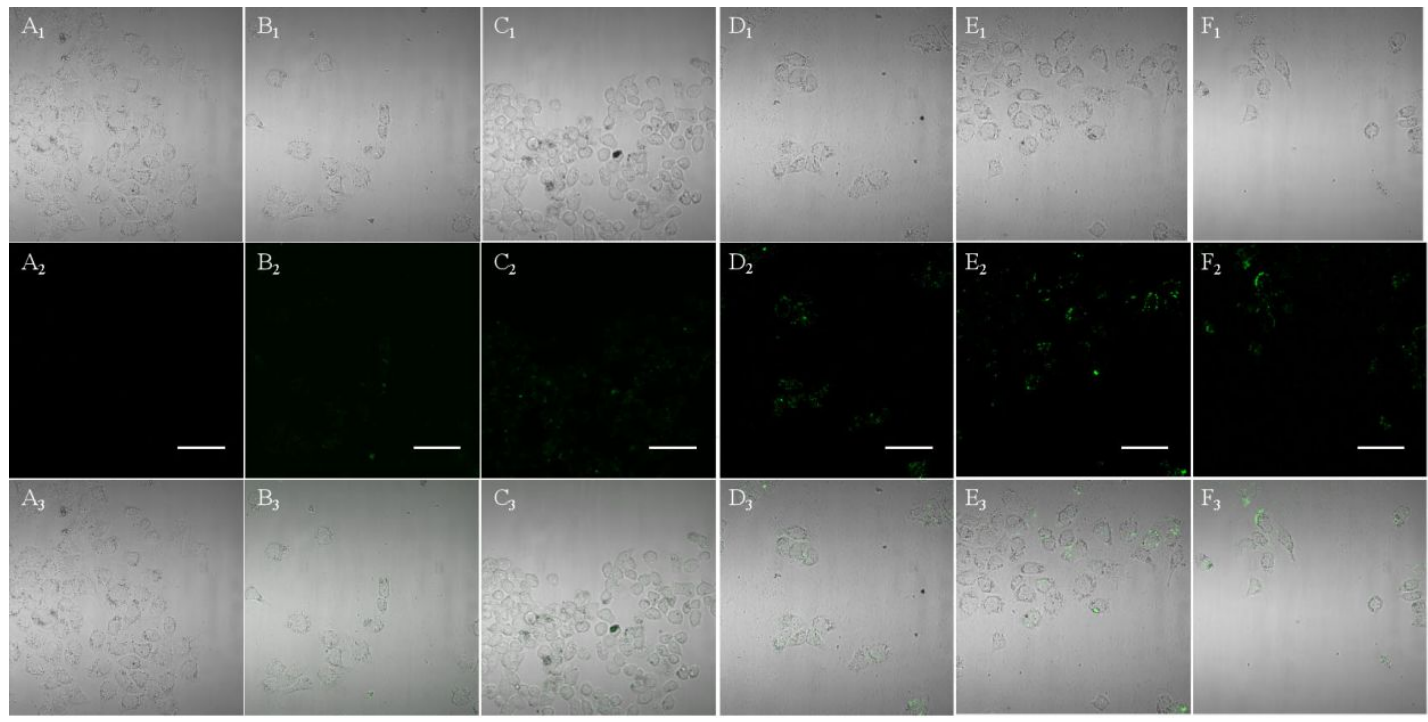

Figure S11. Time course of the confocal images (bright field (up), fluorescence (middle), and the overlay (down)) of HeLa cells incubated with MIL/Apt-F nanosensor (0.3 mg/mL) ((A) 0, (B) $2 \mathrm{~h},(\mathrm{C}) 4 \mathrm{~h}$, (D) $6 \mathrm{~h},(\mathrm{E}) 8 \mathrm{~h}$, and (F) $10 \mathrm{~h}$.) Scale bar: $50 \mu \mathrm{m}$.

Table S1. Comparison of the fluorescence response to BSA for various sensors

\begin{tabular}{|c|c|c|c|}
\hline Probe & Preparation Method & $\begin{array}{l}\text { Relative Fluorescence } \\
\text { Enhancement }\left(F / F_{0}\right)^{[\mathrm{a}]}\end{array}$ & Reference \\
\hline $\mathrm{T}_{10}$-Apt-FAM ${ }^{[\mathrm{b}]}$ & $\begin{array}{l}\text { Physisorption of the aptamer } \\
\text { probe by } \mathrm{GO}^{[\mathrm{c}]}\end{array}$ & $\approx 4.17$ & [4] \\
\hline $\mathrm{NH}_{2}-\mathrm{T}_{10}-\mathrm{Apt}-\mathrm{FAM}$ & $\begin{array}{c}\text { Covalent attachment of the } \\
\text { aptamer probe to GO }\end{array}$ & $\approx 1.78$ & {$[4]$} \\
\hline FAM-labeled ssDNA & $\begin{array}{l}\text { Physisorption of the ssDNA } \\
\text { probe by GO }\end{array}$ & $\approx 23$ & {$[5]$} \\
\hline Apt-FAM & $\begin{array}{l}\text { Physisorption of the aptamer } \\
\text { probe by } \mathrm{Cu}\left(\mathrm{H}_{2} \text { dtoa }\right)\end{array}$ & 2.69 & This work \\
\hline Apt-FAM & $\begin{array}{l}\text { Physisorption of the aptamer } \\
\text { probe by MIL- } 100\end{array}$ & 1.06 & This work \\
\hline
\end{tabular}

[a] Relative fluorescence enhancement $\left(F / F_{0}\right)$ of the sensor toward $2 \mathrm{mg} / \mathrm{mL}$ BSA. Where $F_{0}$ and $F$ are the fluorescence intensities of the sensor before and after treatment with BSA.

[b] Atp is the ATP aptamer. [c] GO is graphene oxide. 